UDC: 332.021.8:63(497.1)"1918/1941"

Александар Касаш Унверзитет у Новом Саду Филозофски факултет alkasas@yahoo.com
Оригиналан научни рад

примљено: 27. март 2013

прихваћено: 1. октобар 2013

\title{
УПОРЕДНА АНАЛИЗА АГРАРНЕ РЕФОРМЕ И КОЛОНИЗАЦИЈЕ НАКОН СТВАРАҢА ПРВЕ И ДРУГЕ ЈУГОСЛОВЕНСКЕ ДРЖАВЕ*
}

Сажетак: У раду се врши синтетичко упоређивање сличности и разлике аграрне реформе и колонизације војвођанског простора након Првог и Другог светског рата, са посебним нагласком да су оне имале многе сличности, пре свега у националној политици обе југословенске државе, у словенизацији ових крајева, али и покушају решавања социјалних прилика.

Кључне речи: аграрна реформа, колонизација, Војводина, став политичких странака о овим питањима-сличности и разлике.

Једно од заједничких и важних питања и особености приликом стварања прве југословенске, али и друге комунистиче државе било је решавање аграрног питања и колонизације, нарочито војвођанског простора. Њему се у различитом историјском контексту посвећивала, у југословенској историографији, али и публицистици, одређена и значајна пажња. Наравно, оно је било нераздвојно са увек пратећом колонизацијом које је било једно од важних питања националне државне политике обеју држава, тј. словенизација (србизација у највећој мери, простора данашње Војводине). И једна и друга југословенска држава овим питањима давала је значајну важност и улогу.

У првој југословенској држави оно се сматрало веома важним питањем, пре свега због спречавања, „револуцисања“ и утицаја бољшевизације и смиривања „сељачких немира“ и утицаја Октобарске револуције, тј. повратника са Источног ратишта и појаве тзв. зеленог кадра.

Друга југословенска држава ове мере сматрала их је као „део револуционарних мера“, првих година, користећи, у највећој мери, искуства

\footnotetext{
* Текст је настао као фазни резултат рада на пројекту Војвођански простор у контексту европске историје (број 177002) Министарства просвете, науке и технолошког развоја Републике Србије.
} 
Совјетског Савеза, његовог односа према сељаштву, али се она спроводила у сасвим другим историјским околностима које су јој давале одређене специфичности.

Овом приликом присутна је чињеница да је као и за прву југословенску државу, национални (српски-словенски) проблем био итекако важан и за југословенске комунисте, мада је за њих било много важније решавање социјалних проблема од националних.

Важна сличност извођења аграрне реформе након стварања и прве и друге југословенске државе да је она имала грађанско обележје, мада у различитим историјским околностима. Њено правно нормирање и извођење било је у рукама државне власти, тј. била је под њеном контролом. Што се тиче колонизационих процеса ту постоје драстичније и огромне разлике, које ћемо у овом раду покушати да што више истакнемо.

Једна од важних, можда најважнијих сличности обе аграрне политике и колонизације били су условљени тиме да да су обе државе важну пажњу поклањањале овим питањима као социјалну. политичку, али и националну меру у својој политици. Заједничко обележје је свакако и чињеница да су обе извођене након светских ратова. И регент Александар Карађорђевић, али и Јосип Броз, зарад својих циљева стварања нове државе, а у циљу мобилизације људства у ратовима, обећали су да ће се у својим државама бити важно решавати тзв. аграрно питање, и да ће сељаци ако узму учешће у њему имати «привилегију» да до земље дођу до тако жељене земље, посебно аграрна сиротиња, Несме се заборавити ни чињеница да су обе државе биле претежно аграрне са преко 70\% и више становништва. ${ }^{1}$

Прва југословенска државна политика још у време Крфског споразума назначила је да ће једна од важних питања бити решавање тзв. добровољачког питања и доделе земље учесницима рата. На својој седници од 17. марта 1917. године влада Србије дала је прецизну формулацију по том питању. Посебно је истакнуто да се југословенским добровољцима који се боре у српској војсци, а који су уврштени у ред бораца даје пет хектара земље, а неборацима три хектара. Југословенски борци нису губили право на ову накнаду „ни у случају ако би од добијених рана или тежих болести преминули, као последица ратних напора делимично, или сасвим остали неспособни за војну службу.“

Сличну одредбу законског карактера донели су и комунисти још док је Други светски рат беснео на југословенским просторима а завршетак рата се приближавао у њихову корист.

Једна од важних карактеристика решавања аграрног питања након Првог светског рата прве југословенске државе била је историјска околност и реалност настала после избијања Октобарске револуције у Русији 1917. године. Наиме, многи повратници са Источног ратишта, а посебно они који су индоктринисани у Октобарској, али и учешћем у социјалистичкој револуцији Беле Куна у Мађарској,

\footnotetext{
${ }^{1}$ Један скромнији покушај указивања на историјски проблем упоредне анализе учинио је Борис Кршев у раду: Uporedne karakteristike agrarnih reformi u Vojvodini u XX veku, „Kultura polisa“, god VIII (2011), br 16, 117-138.
} 
почели су на југословенској (не само војвођанској) територији пропагирати социјалистичке идеје. Нова држава, поред многих објективних проблема, пре свега националних, морала се суочити и са овим важним проблемом, мада је националном интеграцијом Срба, Хрвата и Словенаца 1918. године било примарно решење аграног питања.

Том чињеницом објашњавам да је нова југословенска творевина била оптерећена важнијим националним проблемима, а да је аграрни проблем био у „другом плану“ и зато највероватније га решавала Уредбом а не Законом. Била је суочена чињеницом историјског наслеђа различитих аграрних региона који су се одједном нашли на једном државном простору и овај значајни проблем, као и друга државна усклађивања „оставила за каснија времена“. Мада се и овом приликом мора истаћи чињеница да је прва југословенска држава постојала само нешто више од две деценије и да је било мало историјског времена за решавање тако важних и сложених питања.

Нова држава покушала је да аграни проблем реши одузимењем великих поседа у власништву земљишне аристократије, углавном страног порекла, несловенског, мада је одузимана и земља Србима за које су југословенске власти сматрали да су „мађарони“, на пример породици Дунђерски и то Богдану Дунђерском који је био посланик у Мађарском парламенту до избијања рата ${ }^{2}$. Мада је он из националних разлога, немајући потомство, своје не мало имање оставио првим тестаментом оставио Карловачкој митрополији покушавајући да избегне одузимање земље из аграрне реформе, не добивши њену подршку «завадио» се са регентом Александром Карађорђевићем. Тврдоглави Дунђерски, од тога времена није прешао Саву и Дунав, а са својим великим пријатељем Урошем Предићем састајао се у Земуну.

Субјекти реформе и колонизације у Краљевини Срба, Хрвата и Словенаца били су добровољци (борци и неборци), а карактеристика да је доста њих искористило могућност и право на оптирање, посебно из Мађарске. Важно је, овом приликом нагласити, да је из више разлога, и за једну и другу југословенску државу, данашњи војвођански простор био занимљив не само из економских него и националних разлога. Посебно је у том смислу био занимљив простор Бачке, па и Барање, где словенско становништво није чинило већину. У различитим историјским околностима и Срем је по том питању занимљив простор, па и Банат о чему ће касније у раду бити више речи.

Националну политику прва југословенска држава покушавала је да решава, путем аграрне реформе и колонизације након Тријанонског споразума 4. јуна 1920. године са Мађарском давајући Србима, али и другим словенским народима да

\footnotetext{
${ }^{2}$ Александар Касаш, Тестамент Богдана Дунђерског из 1918. године, «Кровови» Семски Карловци 1997 , бр.39/40.81-84. Из протеста према аграрној и националној политици нове државне политике и не подршке црквених кругова, своју целокупну имовину другим тестаментом из 1940. оставо је Матици српској. (Види опширније: А. Касаш, Коме је Богдан Дунђерски-велепоседник старобечејски и србобрански оставио своје имање? «Зборник Матице српске за историју, бр 55/1997, 169-182.
} 
користе могућност тзв. оптирања, тј. добровољног пресељења на територију новостворене Краљевине СХС. Према новијим истраживањима ради се око двадесетак хиљада таквих особа, који су ту могућност могле да искористе. Вековна национална борба за уједињење са Матицом, овога пута са првом југословенском државом, пре свега Срба давала им је могућност добровољног избора. Овај процес није био нимало једноставан. Многи су се двоумили из више, пре свега економских разлога јер им је југословенска држава могла да обећа само пет катастарских јутара, а на свако дете још пола јутра. Мада је од почетка тај процес оптирања требао да се изврши за шест месеци ипак су многе потешкоће и дилеме условиле да је оптирање вршено у неколико махова, а ово право искористило је две трећине махом српског сиромашнијег становништва. Процес оптирања завршен је 1. новембра 1930. године. ${ }^{3}$

Вредно је овом приликом истаћи, да је мађарска аграрна сиротиња, мада посебно у Бачкој била искљичена из агране реформе, баш због права на оптирање. Слично је било и са немачком националном мањином.

Проблем оптирања српског становништва из румунског дела Баната и обрнуто имало је своје специфичности, пре свега у сложеним граничним проблемима двеју држава, румунске и југословенске, посебно око поделе Баната и француске улоге у њој, чиме се овом проблему давао деликатан и осебан историјски, национални значај.

Комунистичка власт није применила тај метод оптирања. Постојала је идеја размене становништва и да се оно Мађарској да се плебисцитом изјасни о жељи да живи у ФНРЈ. Чак су постојали и пројекти о размени становништва, али о томе ће касније бити речи.

Значајне политичке групације које су креирале стварање, пре свега прве југословенске државе, биле су веома свесне колико је решавање аграног питања, а тиме и колонизационог процеса важно за функционисање новонастале државе. У сложним ратним приликама од Нишке декларације, Крфске, али и других ратних циљева, пре свега српских, размишљало се и о важним аграним решењима за функционисање нове државе, за које се и тада размишљало да је у будућнсти од посебног значаја.

Радикали су били исувише свесни да је међу аграрном сиротињом значајан политички (бројчани) изборни потенцијал. Још 20. јуна 1919. они су назначили да ће након стварања нове државе, доћи до укидања свих врста феудалних односа, посебно чивчијских у Македонији Старој Србији и кметовских у Босни и Херцеговини. Били су и против великих поседа, ослањајући се основним принципом да „земља припада оном који је обрађује“. Вредно је, овом приликом истаћи да ће се и југословенски комунисти 1945. године се позивати на овај принцип. Поред многих дивергентних политичких ставова радикали ће значајније утицати тек када је у Пашићевој влади образованој 1. јануара 1921. године министар за аграрну реформу постао Никола Узуновић преко кога су радикали могли знатно да

\footnotetext{
${ }^{3}$ Гојко Маловић, Сеоба Срба у Матииу (оптирање Срба у Мађарској 1920-1931. књ. 1, Н. Сад 2100,585.
} 
утичу на аграрну политику прве југословенске државе.

Важно обележје услова у којима се изводила и прва и друга аграрна реформа и колонизација су велике социјалне, економске па чак и цивилизацијске разлике. Север, тј. подручја која су се налазиле у оквирима Аустро-Угарске били су знатно развијенија подручја. Мада се ту мора истаћи да је Далмација у аграрном смислу била такође неразвијена.

Посебну карактеристику првој аграрној реформи и колонизацији дају различита гледишта и предлози о решењу аграрног питања одређених политичких групација, од радикала до социјалиста. Њихове расправе и ставови трају све до 1921. године, до доношења Видовданског устава. Мада исувише свесне важности решавања овог питања у условима појаве тзв. зеленог кадра и социјалних немира инаугурисала се јединствена политичка платформа доношењем Претходних одредаба 25. фебруара 1919. године. То је било у ствари опште политичко изјашњавање за прерасподелу земљишног фонда у Југославији у корист беземљашког и сиромашног сељаштва. ${ }^{4}$

Вредно је поменути да су вредни и значајни политички прваци исте политичке оријентације, северно од Саве и Дунава (ту све га мислим на данашњи војвођански простор) упозоравали на разне начине чак и били директни противници аграрне реформе. Чак је и сам Јаша Томић изнео своје гледиште сматрајући да ако се земљиште буде разделило приватним газдинствима да би дошло до разних махинација и дошло до поновног стварања велепоседа. Преллагао је да се земља подели у „вечити закуп“.5 Своје противљење изнео је и Јоца Лалошевић. Чак је саставио и посебан Меморандум, и лично са својим погледима упознао регента Александра прилком посете Сомбору крајем јула 1919. Упозоравао да се тако важно питање неможе решавати тзв. Претходним одредбама већ да оно мора имати законски карактер. Основна његова реакција на начин брзоплертости доношења овако важних питања за нову државу, сматрао је да њена социјална димензија несме да буде приоритетна мислећи на спречавање бољшевичних утицаја. Залагао се за очување великог велепоседа. ${ }^{6}$

Још један од значајних политичких интелектуалаца Славко Шећеров, експерт Демократске странке за аграрно питање, оценио је приликом именовања радикала почетком 1924. Светозара Станковића за државног подсекретара за аграрну реформу да је у односу на решење аграрног питања превагнуло радикалско решење. ${ }^{7}$

Војвођани су сматрали да њима припада место министра за аграрну реформу. То им је и успело у последњој влади пред увожење Шестојануарске диктатуре када је именован Дака Поповић 27. јуна 1928. који је имао намере да реформом задовољи и беземљаше националних мањина, истина не у Војводини,

\footnotetext{
${ }^{4}$ Никола Гаћеша, Радови из аграрне историје и демографије, Нови Сад 1995, 127-128.

${ }^{5}$ Slobodan Bjelica, Radikali u Vojvodini 1919-1929, Beograd 2004, 48.

${ }^{6}$ Саша Марковић, Политичка биографија Јована Јоче Лалошевића, Сомбор 2011,146.

${ }^{7}$ S. Bjelica, Radikali..,50.
} 
него на југу нове државе. ${ }^{8}$

Важно питање прве југословенскоже државе у аграрном и колонизационом питању било је тзв. добровољачко питање. Већ 18. децембра 1918. године оно је добило законску форму донетом Уредбом о добровољцима по којој се добровољцем сматрао свако онај који се у српску војску добровољно јавио до 18. новембра $1918 .{ }^{9}$ Након доношења Видовданског устава допуњена је ова Уредба 30. децембра 1921. године по којој су добровољцима сматрана и она лица „за које се утврди да су својим радом и пожртвовањем помогли остварењу националног ослобођења и уједињења“.

Најактрактивнија за колонизацију прве, а видеће се касније и друге била је територија Бачке у којој је словенско становништво било у мањини, ако се саберу Мађари и Немци. После 1918. у Бачкој је створено 64 добровољачке колоније, Банату 42, а у Срему 24, укупно $160 .^{10}$

Занимљива су називи места, не само у Бачкој, као на пр. Мишићево, Степановићево, Сириг, Томићево, Пашићево, Нови Жедник, али и у Банату Александрово, Војвода Степа итд.

Стварање добровољачких насеља нису у најбољој мери одговорила, пре свега економским, социјалним, али и политичким циљевима. Економски развитак насеља текао је веома споро. Представљале су мале затворене економске целине са ниском производњом, мада их је држава економски помагала. Економска диференцијација међу становништвом готово да није ни постојала. ${ }^{11}$ Ни политички, војни, ни национални разлози нису у потпуности испуњени, у највећој мери. Места створена близу румунске границе изгубиле су на значају посебно стварањем Мале антанте и југословенско-румунским разграничењем. У Бачкој није у многоме промењена национална структура, а слабљењем мађарског ревизионизма, у прво време, није доносило резултате у њиховој одбранбеној функцији граница нове југословенске државе.

Приликом колонизационог процеса добровољци су чинили основно ткиво колонизације, сматрани су људима нове државе и у односу на колонисте са другачијим статусом налазили су се у повлашћенијем положају (закуп земље и одштету за добијену земљу за њих је плаћала државе, добијали су квалитетнију земљу и земљу ближе насељу, имали су „лакши приступ“ кредитима за градњу кућа, куповину пољопривредних радила, хране и семена итд.)

Други светски рат знатно је променио у државно-правном смислу данашњи војвођански простор. Разбијањем прве југословенске државе, посебно када је 10. априла 1941. године Хортијева Мађарска сматрала да је не обавезује Уговор о вечном пријатељству из децембра 1940. Већ следећег дана приступила је „враћању оних територија које су јој неправедно одузете Тријанонским уговором из 1920.“

\footnotetext{
${ }^{8}$ Isto,

${ }^{9}$ Б. Лекић, Аграрна реформа..,152.

${ }^{10}$ Н. Гаћеша, Радови из аграрне.., 373.

${ }^{11}$ Н. Гаћеша, Радови из аграрне...246.
} 
Бачка је у аграрно поседовним и колонизационим променама имала најспецифичнији карактер. Основа мађарске политике било је враћање на стање пре 1914. године. Не само да се приступило ревизији аграрне реформе него се приступило протеривању добровољачког становништва насељеног након орвог светског рата. Да је оно било раније припремано сведочи један елаборат сачињен још 20. марта 1941. под насловом Проблеми југословенско-мађарских односа кога је израдио министарски саветник Пал Бала у којем је посебно назначио да ће исељење добровољачког становништва досељавање тзв. Чанго Мађара из Ердеља бити приоритетни задатак јер су они већином насељени око Бачког канала. ${ }^{12}$ Непосредно пред рат, тачније 9. априла 1941. Хенрих Верт је сматрао да би било довољно населити око десет хиљада ових мађарских породица како би се у тим крајевима „Мађарство ојачало“. ${ }^{13}$ Већ једна од првих наредби мађарских власти била је наредбибило је протеривање свих оних лица који нису имали завичајност Аустро Угарске пре 1918 а на њихово место насељена је мађарска сиротиња из Трансилваније. Она је након ослобођења протерана из Бачке, а увођењем Војне управе за Банат, Бачку и Барању заузет је репресивнији став према Мађарима, нарочито због збивања у Јужној Бачкој (Шајкашкој, Новом Саду и Бечеју) тзв. рацији из јануара 1942. године. Касније је тај став према Мађарима промењен због прилика у Мађарској.

Као и у време Првог светског рата тако и у Другом партизански покрет на челу са комунистима обећали су сељацима да ће се ако приступе њиховом покрету након рата извршити аграрна реформа под геслом «да земља припада ономе који је обрађује». Само су они могли да рачунају на земљу оних који су стали на страну окупатора. Тако је након ослобођења источних и североисточних југословенских крајева донета одлука АВНОЈА 21. новембра 1944. године о одузимању земље њима, али је могла да рачуна и на целокупну немачку имовину за коју је нова власт, не само у нашој држави сматрала да је крива за избијање рата. Однос према немачкој националној мањини није био својствен само на нашим просторима.

Колики су значај југословенски комунисти давали колонизацији говори чињеница да је само два дана након формира Демократске Федеративне Југославије, 9. марта 1945. Министаство за колонизацију на челу са познатим социологом села Сретеном Вукосављевићем који је имао одређена искуства изводећи аграрну реформу и колонизацију између два светска рата.

Формирањем и оснивањем Демократске Федеративне Југославије 7. марта 1945. биле су остварене одлуке Кримске конференције о формирање нове државе у којој су у југословенској влади били и некопромитовани предратни политичари, а на њеном челу били су Јосип Броз и Иван Шубашић. Од тада престаје да постаји тзв. паралелизам влада од новембра 1943. тј. Другог заседања у Јајцу и партизански покрет је тим чином званично међународно признат, мада је рат на југословенском простору још трајао.

\footnotetext{
${ }^{12}$ Kasaš..,1996,24.

${ }^{13}$ Sajti, navedeno delo, 210.
} 
Ослобођењем југословенске територије и завршетком рата, маја 1945. југословенски комунисти отпочињу политичку борбу за остварење својих политичких циљева и борбом за апсолутну власт која се могла остварити једино на изборима и доношењем Устава. Већ за 7. август 1945. доноси се одлука о сазивању Трећег заседања АВНОЈ-а у Београду чија најважнија одлука је била да се 10 . августа формира Привремена народна скупштина. У њеном раду су учествовали и неки грађански политичари од којих је свакако најзначајнији био Милан Грол. Мада је њен основни задатак био припрема за општенародне демократске изборе, југословенски комунисти су искористили свој политички монопол и победничку еуфорију након рата да један од важних одлука Скупштине буде и доношење Закона о аграрној реформи и колонизацији 23. августа 1945. којим је успостављен земљишни максимум на 25 ха обрадиве и 45 ха необрадиве земље и давањем исте у беземљашима ситним сељацима у трајно власништво. Уз велико противљење грађанских посланика који су се противили његовим доношењем „авионском брзином“ комунисти су веома добро проценили да ће његовим доношењем привући велики број гласача на наредном изјашњавању и изборима који ће одлучивати о томе да ли ће нова држава бити монархија или република.

Колонизациојом је руководио Аграрни савет Демократске Федеративне Југославије. Он је имао деликатан задатака да «што правичније изврши прерасподелу тзв. насељеничких квота. Посебно је у Црној Гори постојало велико интересовање, мада је за њу одређена квота од седам хиљада породица које су већ тада сматрале да „оне треба да добију најбољу, немачку, војвођанску земљу, а пре свега немачке куће“ који су били, „главни народни непријатељи“. Лична познанства, не мали утицај тада водећих партизанских кадрова, био је од не малог значаја. Овде посебно истичем пример Блажа Јовановића, председника владе Црне Горе, који је сматрао да становништво из Црне Горе треба да насели богата немачка места поред Великог Бачког Канала.

Решење о дозволи пресељења колониста на војвођанске просторе донело је Министарство унутрашњих послова још 17. марта 1945. године, док је још рат трајао што недвосмислено сведочи да су наредна миграциона кретања била итекако планска и део социјалне, политичке и националне политике југословенских комуниста. ${ }^{14}$ На основу прецизних молби за колонизацију, овом приликом истичем да је она била добровољна, да је међу колонистаима стварана илузија да их «у Војводини чека заслужени мед и млеко». На основу прецизних колонизационих захтева одређена су насеља по срезовима. Овде као и приликом колонизације из

\footnotetext{
${ }^{14}$ Каснијих година нарочито, крајем 20. века многи квазиисторичари покушавали су „преиспитивајући улогу Јосипа Броза“, па и у овим збивањима. По мени, долазили су до погрешних закључака, „да је Јосип Броз смишљено празнио српски етнички простор“, мада сматрам да је све до септембра 1943. године партизански покрет имао српско обележје и није случајно да су у колонизацији имали предност они који су у рату били учесници од 1941. Социјални елеменат био је присутан. Боље куће, имовину „швапску“, добили су баш те породице. Своју правоверност идеолошку, баш те породице испољавале су, не само рушењем „фашистичких споменика по сеоским гробљима“, већ и православних светиња за које се оновремено сматрало да су „класни и идеолошки непријатељи“.
} 
других крајева, становништво је изражавало жељу да буде у компактним насељима. Била су то не само родбинске, племенске везе него и жеља да се у новој средини боље снађу јер је задружни, племенески и дух узајамне помоћи био веома присутан. Тако су Врбас населили Црногорци из Никшићког среза, Бачко Добро Поље из среза Дурмиторског, Секић (Ловћенац) из среза Цетињског, Црвенку из среза Даниловградског, Стари Сивац из среза Бјелопољског, Црвенку Даниловградског, Нови Сивац Пљеваљски, Савино Село срез Берански и Андријевачки, Змајево и Равно Село срез Подгорички. Фекетић срезови Херцегновски и Котрски и Крушћић срез Колашински.

Нејасне представе куда одлазе колонисти чак и код највишег руководства. Тако је, примера ради Владо Шегрт, министар пољопривреде и сточарства у Народној влади Босне и Херцеговине који је и сам предлагао колоностима да понесу што мање ствари, пошто их у Војводини очекује све што им је потребно за бољи и квалитетнији живот. У својој пропаганди потребе колонизације чак је и претеривао и улепшавао ситуацију која их тамо очекује.

Својом планском колонизационом политиком југословенски комунисти водили су рачуна које ће војвођанске области бити насељени колонисти из разних југословенских крајева. Тако није случајно примера ради да су Личани насељени у Апатин и околна места. Они су као традиционално граничарски елеменат требали у новој држави да постану „одређена одбрамбена снага нове државе“ према суседној Мађарској као на пример и Срби из Босне у Банатско Ново Село и друга насеља као одбрамбени елеменат према Румунији.

Разлог насељавања Словенаца у Вршац био је првенствено из разлога обраде некадашњих немачких винограда, али су се убрзо вратили у свој крај из више разлога. ${ }^{15}$

Македонци нису такође насељени у близини Београда у Јабуку. Они су као добри повртари имали задатак да главни град снабдевају пољопривредним производима.

Процес прилагођавања колониста новим условима текао је не без тешкоћа. Нови услови живота и рада био је прави цивилизацијски шок. Била је и велика неписменост међу њима. У решавању многих проблема помагале су тзв. масовне антифашистичке организације, пре свега, Народни фронт, Синдикат, АФЖ итд.

Насељеничке партизанске породице требале су да буду носиоци револуционарних мера нове власти и њена најзначајнија подршка у сваком смислу. $\mathrm{He}$ само да су својим чињењем доказивали приврженост тим мерама чак су испољавали и много радикалнији став у односу на староседелачко становништво исте идеолошке оријентације.

Становништво из паснивних крајева приликом колонизације испољавало је посебну жељу да се насели, тј. преселе читаве породице из старог завичаја у нова насеља чак и регионе.

\footnotetext{
15 Комунисти су их у првој варијанти желели населити у Бачку али је превагнула идеја да би се тиме ојачао католички блок и да их треба одвојити од Хрвата и Мађара.
} 
Мењани су и називи места, углавном су имена давана по народним херојима из крајева из који су досељавани. Примера ради: Чиб је променио име у Челарево по Здравку Челару, Букин у Младеново др Младену Стојановићу, Торжа у Савино Село у спомен на Саву Ковачевића, Мартиница у Лукићево у сећање на Вељка Лукића Курјака, Парабућ у Ратково у спомен на Ратка Павловића. Имена су давана и на носталгична сећање на родни крај. Тако је Сарча постала Сутјеска, Буљкес Бачки Маглић (по планини Маглић), Шупљаја је добила назив Крајишник тј. колониста који су дошли из Босанске крајине, Секић у Ловћенац (досељеници из подловћенских села) итд. ${ }^{16}$

Један од особености колонизационих процеса у Војводини након Другог светског рата било је и насељавање грчких партизана у време грађанског рата који се водио у Грчкој. Наиме, Грчка Комунистичка партија је замолила југословенске комунисте да прихвате неколико хиљада њих и тиме помогну тешку ситуацију у којој су се они нашли, а југословенски комунисти имали важну улогу у њему. Александар Ранковић је једним писмом замолио Јована Веселинова да за њих нађе погодно насеље у Војводини које би било екстериторијално. Веселинов му је предложио Буљкес (Бачки Маглић) који је готово стопроцентно било између два рата немачко насеље и после логорисања Немаца готово било испражњено. У њему је насељено преко четири хиљаде Грка. ${ }^{17}$ Они су у овом несељу имали екстериторијалност. Поред тога што су имали свој новац, школу, штампу (Глас Буљкеса), нису могли да напуштају, сем специјалних дозвола насеље, мада су имали своју омладинску бригаду на изградњи пруге Шамац-Сарајево. Ове грчке избеглице доживеле су трагичну судбину наредних година везане за сукоб Југославије са земљама Информационог бироа. Велики број изјаснио се за Стаљина, неки ликвидирани, а већина их је морала напустити место, а каснијих година то село населили су Срби из Босне и Херцеговине.

За разлику од политике прве југословенске државе која је предвиђала оптирање Срба и другог словенског становништва, Брозова Југославија је предвиђала тзв. размену становништва али се од тога одустало пошто је много више Мађара живело на просторима Југославије него Срба и Хрвата у Мађарској. Радикалнији став имао је министар за колонизацију који је у многоме одударао од државне политике према Мађарима. ${ }^{18}$

У Војводини је формирањем земљишног фонда од фебруара до маја 1946 у циљу извођења аграрне реформе отпочело са доделом земље. У земљишни фонд према подацима Николе Гаћеше највише је ушло велепоседничке земље, близу 1200 поседа са површином од 84.712 ха, немачких поседа 68.035 са површином од чак 389.256 ха, земљорадничке земље изнад максимума 5.695 са површином од 74.289

\footnotetext{
${ }^{16}$ N. Gaćeša, Agrarna reforma i kolonizacija u Jugoslaviji 1945-1948, Novi Sad 1984,352.

${ }^{17}$ Види опширније Милан Ристовић, Експеримент Буљкес, Нови Сад 2007.

${ }_{18}$ А. Касаш, Сретен Вукосављевић о решењу националног питања у Бачкој после Другог светског рата, „Зборник Матице српске за историју“, бр. 58/1998, 219-223.
} 
ха итд. Укупно је под удар аграрне земље дошло 87.393 поседа са чак 668.412 ха. ${ }^{19}$ Јавне аграрне расправе давале су посебну карактеристику онога времена, са посебном социјалном димензијом.

Аграрна реформа, коју је спроводила нова власт сматрала је да је то само прелазни облик решавања аграрног питања. Имала је намеру да стварањем сељачких радних задруга следи совјетски модел посебно од 1949. године. Убрзо је већ кроз неколико година доживео неуспех, не само због сукоба са земљама Информационог бироа.

\section{Литература:}

A Sajti Enikó, Mađari u Vojvodini, Novi Sad, 2010.

Bjelica Slobodan, Radikali u Vojvodini 1919-1929, Beograd 2004.

Gaćeša L. Nikola, Agrarna reforma i kolonizacija u Jugoslaviji 1945-1948, Novi Sad 1984.

Исти, Радови из аграрне историје и демографије, Нови Сад 1995.

Isti, Agrarna reforma i kolonizacija u Jugoslaviji 1945-1948, Novi Sad 1984.

Касаш Александар, Тестамент Богдана Дунђерског из 1918. године, Кровови Сремски Карловци 1997, бр.39/40.81-84.

Исти, Коме је Богдан Дунђерски-велепоседник старобечејски и србобрански оставио своје имање? Зборник Матице српске за историју, бр 55/1997, 169-182.

Isti, Mađari u Vojvodini 1941-1946, Novi Sad 1996.

Исти, Сретен Вукосављевић о решењу наиионалног питања у Бачкој после Другог светског рата, Зборник Матице српске за историју, бр. 58/1998, 219-223.

Kršev Boris, Uporedne karakteristike agrarnih reformi $u$ Vojvodini u XX veku, Kultura polisa, god VIII, br 16 (2011).

Лекић Богдан, Аграрна реформа и колонизација у Југославији 1918-1941, Београд 2002.

Мицић О Милан, Развитак нових насеља у Банату (1920-1941), рукопис докторске дисертације брањен на Филозофском факултету у Београду 2011.

Милан Ристовић, Експеримент Буљкес, Нови Сад 2007.

\footnotetext{
${ }^{19}$ Н: Гаћеша, Аграрна реформа у Југославији..,191.
} 


\title{
COMPARATIVE ANALYSIS OF THE AGRARIAN REFORM AND COLONIZATION AFTER THE CREATION OF THE FIRST AND SECOND YUGOSLAV STATE
}

\begin{abstract}
Summary
The work is carried out synthetic comparison of similarities and differences of agrarian reform and colonization of the Vojvodina area after the First and Second World Wars, with special emphasis that they have many similarities, especially in the national politics of both Yugoslav states, the Slavic influence of these areas, and try to solve social conditions.
\end{abstract}

Keywords: agrarian reform, colonization, Vojvodina, attitude of political parties on these issues-similarities and differences. 